Terr. Atmos. Ocean. Sci., Vol. 17, No. 4, 829-843, December 2006

\title{
Gas Hydrate Stability Zone in Offshore Southern Taiwan
}

\author{
Wu-Cheng Chi ${ }^{1}{ }^{*}$, Donald L. Reed ${ }^{2}$, and Chih-Chin Tsai ${ }^{3}$
}

(Manuscript received 17 January 2006, in final form 6 November 2006)

\begin{abstract}
Methane hydrates are considered a major potential source of hydrocarbon energy and could be important in meeting natural gas demand in the future. To study the feasibility of recovering methane from the offshore southern Taiwan region and its impact on many geological processes, it is necessary to know the total amount of hydrate in the region; something that is still unclear. Here we take the first step using a bottom-simulating reflector (BSR) to estimate the total volume of the stability field that can hold hydrates in the sediments offshore of southern Taiwan. We used a dense grid of 6-channel and 120-channel reflection profiles to study the distribution and sub-bottom depth of a BSR. BSRs are marked by a reversed polarity reflector that increases in sub-bottom depth with increasing water depth, suggesting that BSRs mark the base of methane hydrate stability zones. For offshore Taiwan a BSR is located in offscraped sediments derived from the Taiwan orogen and the Chinese continental margin. These sediments may have high amounts of organic carbon, thereby providing a source for the methane. We document the areal extent and subbottom depth of BSRs covering a $45000 \mathrm{~km}^{2}$-wide region. The BSRs were classified into three categories based on how well they fit the seismic characteristics of the BSR associated with hydrates. Q1 BSR fits with all the expected seismic attributes to be found at the base of a hydrate boundary, while Q2 and Q3 BSRs are possible and probable reflectors resulting from such a boundary. We then estimate the volume of the hydrate stability zone bounded between the seafloor and the mapped BSRs in the offshore region.
\end{abstract}

\footnotetext{
${ }^{1}$ Institute of Earth Sciences, Academia Sinica, Taipei, Taiwan, ROC

2 Department of Geology, San Jose State University, San Jose, USA

3 Institute of Oceanography, National Taiwan University, Taipei, Taiwan, ROC

* Corresponding author address: Prof. Wu-Cheng Chi, Institute of Earth Sciences, Academia Sinica, Taipei, Taiwan, ROC; E-mail: chi@earth.sinica.edu.tw
} 


\begin{abstract}
At least $1023 \mathrm{~km}^{3}$ of the hydrate stability field is underlain by the highest quality BSRs while as much as $11522 \mathbf{~ k m}^{3}$ is underlain by all mapped BSRs. We then speculated on the total amount of hydrate stored in the region using published regional porosity-depth relations and assuming a range of saturation values of hydrates in the pore spaces. Hydrate storage can be better estimated once additional porosity and saturation information becomes available.
\end{abstract}

(Key words: Bottom-simulating reflector, Methane hydrate, Taiwan)

\title{
1. INTRODUCTION
}

Methane hydrates are ice-like crystalline solids formed from a mixture of water and methane molecules. Most hydrates have been found in deep ocean sediments where there is a sufficient supply of methane and where pressure and temperature ranges between $0.2-5 \mathrm{MPa}$ and $0-25^{\circ} \mathrm{C}$, respectively, as per Kvenvolden and McMenamin (1980). World storage of the hydrates has been estimated to range from $10^{18}$ to $10^{19} \mathrm{~g}$ (e.g., Milkov 2004; Kvenvolden 1988). One volume of hydrate can contain up to 164 volumes of free gas (Kvenvolden 1993), therefore is a very condensed form of gas. The hydrates and any free gas trapped below the hydrate stability field may provide a significant hydrocarbon resource in the future (Kvenvolden and McMenamin 1980; Kvenvolden 1993).

Methane hydrates also influence a number of important submarine processes (Kvenvolden 1993). Development of the offshore seabed may be influenced by seafloor instability and mass wasting, both of which are potentially affected by hydrate formation and decomposition. Methane hydrate in marine sediments may form a significant global sink of methane, a gas that is about 20 times more effective as a greenhouse gas than carbon dioxide. Variations in waterbottom temperature or the position of the sea level may influence the stability of hydrate, and in some cases, could result in the release of additional methane into the atmosphere and potentially influence climate (Kvenvolden and McMenamin 1980; Kvenvolden 1993). In addition, as the submarine accretionary prism grows or even emerges from the sea, some hydrates will decompose into gases and get released into the atmosphere. The volume of the hydrate stability zone needs to be calculated before scientists can estimate the amount of gas which could be potentially released into the atmosphere through this process.

Recently some engineering projects have been proposed to use deep-sea sediments to safely store man-made carbon dioxide (House et al. 2006). These projects will use hydrates to seal liquid-phase carbon dioxide that is denser than its surrounding water. Other proposals include storing methane in deep-sea sediments to reduce the risk of storing it in on-land tanks. Evaluation of such projects would benefit from a better understanding of the regional scale hydrate stability field.

Seismic profiles have been extensively used in hydrate research. Surface seismic data can image hydrate formations through the presence of a bottom-simulating reflector, or BSR that is sub-parallel to the topography of the sea floor (Shipley et al. 1979). These seismic reflectors 
are generated by the acoustic impedance contrast at the base of a sediment layer containing methane hydrate (Shipley et al. 1979) and usually are at a sub-bottom depth of several hundred meters. The increase in temperature with depth below the seafloor causes methane hydrate to become unstable and decompose, despite increasing pressure. As a result, the base of the methane hydrate defines a "phase boundary" that separates the stable gas hydrate above from a field of instability below. Because they are not structural reflectors, they can sometimes cut across reflectors generated by sediment layers (Tucholke et al. 1977; Shipley et al. 1979).

To estimate the total hydrate storage in this region, one needs the following information: (1) total volume of the hydrate stability zone between the seafloor and the mapped BSRs; (2) the pore space percentage in the sediments within the stability zone: and (3) the saturation value of the hydrates in the pore space. Here we are interested in the stability field between the seafloor and the BSR. We study the distribution of the BSR south of Taiwan using migrated 6-channel and 160 -channel reflection profiles. This region is characterized by a large accretionary prism formed along the boundary between the Eurasian and Philippine Sea plates. BSR sub-bottom depths were compiled in the region of subduction and that of collision. We use a velocity-depth relation published in Hamilton (1980) to convert travel-time measurements to depth in meters. We then estimate the total volume of the hydrate stability zone using the distribution of the BSR and its associated sub-bottom depth.

Furthermore, we have estimated the hydrate storage in this region based on an average depth-dependant porosity function, and a range of reasonable hydrate saturation values. The precise values of porosity and hydrate saturation might vary spatially in this region. And this preliminary hydrate storage estimate can be modified when additional information on the regional porosity and saturation become available.

\section{GEOLOGICAL SETTING OF TAIWAN COLLISION}

The offshore Taiwan accretionary prism (Fig. 1) is located on the boundary between the Eurasian plate and Philippine Sea plate where oceanic lithosphere of the South China Sea is subducting eastward beneath the Philippine Sea plate (Bowin et al. 1978; Ho 1986). The prism is bounded on the west by the Manila Trench, and the forearc basin of the North Luzon Trough to the east. Near Taiwan, subduction changes into an arc-continent collision where the Chinese continental margin enters the subduction zone (Suppe 1981). East of the trench, the submarine prism contains three distinct structural domains (Reed et al. 1992; Fig. 1): (1) a lower slope domain composed of mostly west-vergent ramp anticlines; (2) an upper slope domain with highly discontinuous reflections, suggesting intense deformation, and, possibly, out-ofsequence thrusting and underplating; and (3) a backthrust domain located along the rear of the prism. The North Luzon Trough, a forearc basin, is truncated by the juxtaposition of the rear of the prism and the volcanic arc along backthrusts in the region of collision.

\section{DATA ANALYSIS}

This study is based on data acquired during marine geophysical surveys (Fig. 2) con- 
ducted in 1990 aboard the R/V Moana Wave of the University of Hawaii and the 160-channel seismic reflection survey in 1995 aboard R/V Maurice Ewing of Columbia University as part of the onshore-offshore seismic experiment known as TAICRUST. The 6-channel data were processed at UC Santa Cruz and San Jose State University using the SIOSEIS processing software with the following sequence: debias correction, resample to $4 \mathrm{msec}$, spectral analysis, quality control, near trace gather, shot gathers, trace editing, geometry, auto-gain control, spiking deconvolution, normal-moveout, stack, filter, predictive deconvolution, water-bottom mute, trace weighting, filter, auto-gain control, 4-fold stack section plot, F-K time migration at $1500 \mathrm{~m} \mathrm{sec}^{-1}$,

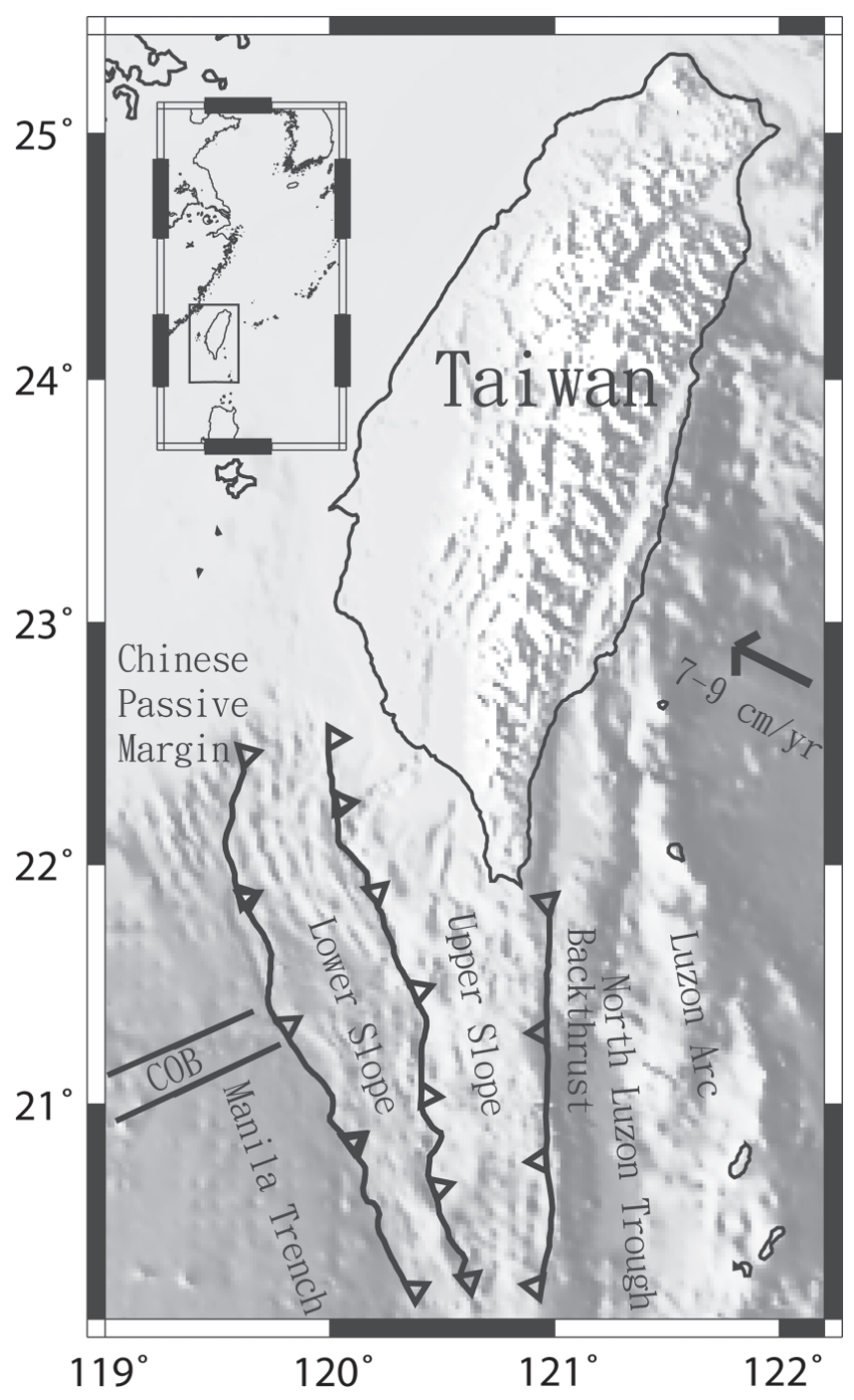

Fig. 1. Offshore tectonic framework map (after Reed et al. 1992). The basemap shows bathymetry of this region. We have plotted the lower slope domain, upper slope domain, and backthrust domain. COB: ContinentOcean Boundary. 


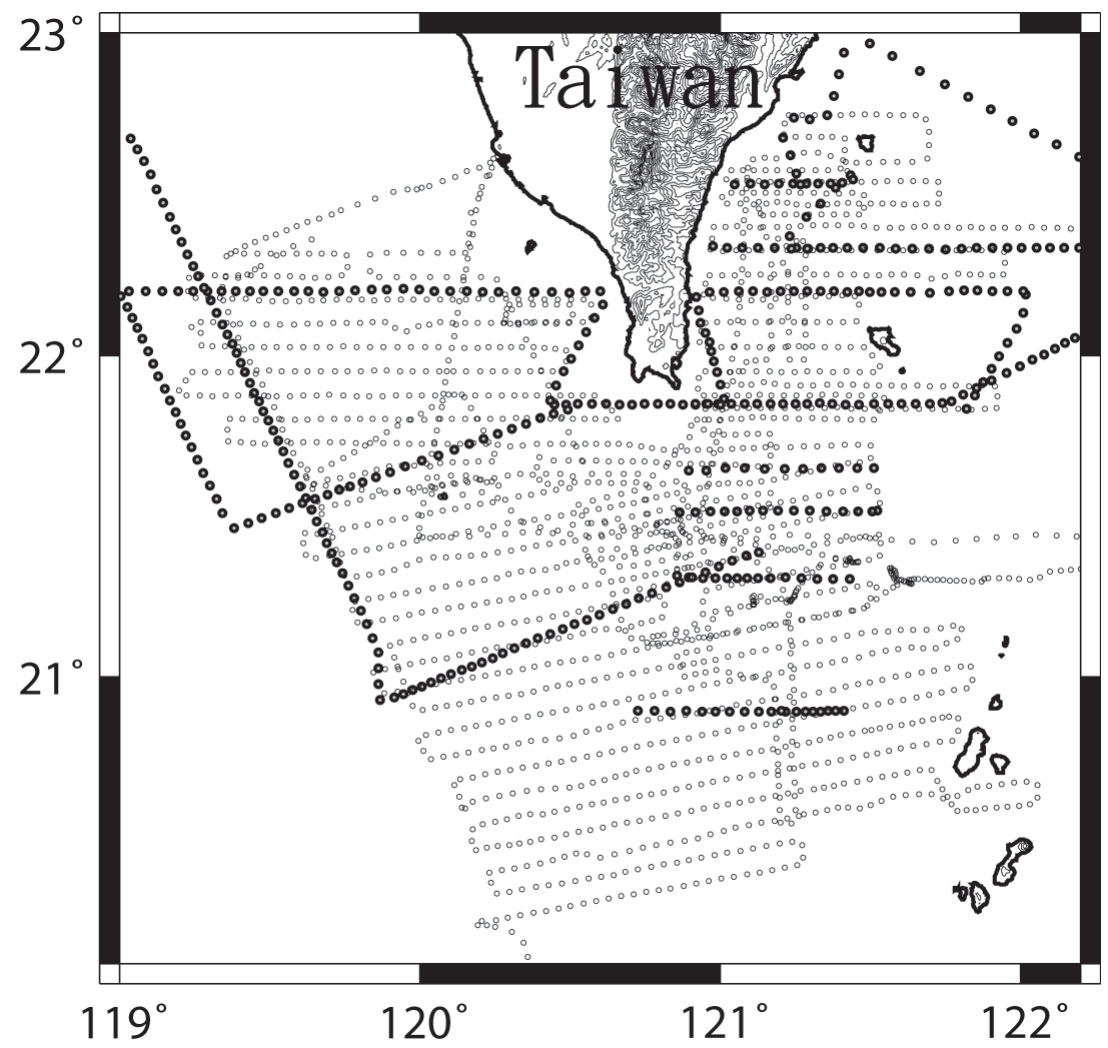

Fig. 2. Tracks of 1990 6-channel seismic data (small circles) collected during the R/V Moana Wave cruise (after Reed et al. 1992) and 160-channel seismic data associated with the 1995 TAICRUST experiment (large circles).

filter, AGC, and finally, migrated section plot (Reed et al. 1992). The 160-channel reflection data were processed at University of Hawaii using ProMAX. This dataset, with large sourcereceiver offset and detailed interactive velocity analysis (0.6 - $1.2 \mathrm{~km}$ spacing) after DMO, provides good velocity information in this region, especially at shallow sub-bottom depths where BSRs are located. More than 8000 kilometers of seismic reflection profiles were examined covering a region of $45000 \mathrm{~km}^{2}$.

We have made a determined effort throughout the study to separate reflectors associated with water-bottom reverberations from BSR identifications. In some cases, BSRs located near predicted water-bottom reverberation time were discarded. The reverberation usually shows strong over-migration artifacts and is easy to identify. The characteristics of the BSR in this 
region were discussed in details in Chi et al. (1998). The BSR (Fig. 3) was identified along survey lines and each pick was assigned to one of three categories according to the confidence level of the identification (Q1, Q2, or Q3). Q1 represents a clear BSR, Q2 a probable BSR, and Q3 a possible BSR. The Q1 category includes BSRs with the following reflector characteristics: (1) subparallel to the seafloor in shallow sub-bottom depths; (2) reverse polarity with a single symmetrical pulse; and (3) a strong coherent reflection that cuts across bedding. The Q2 cat-

(a)

Lat i tude : $21^{\circ} 10^{\prime} \mathrm{N}$

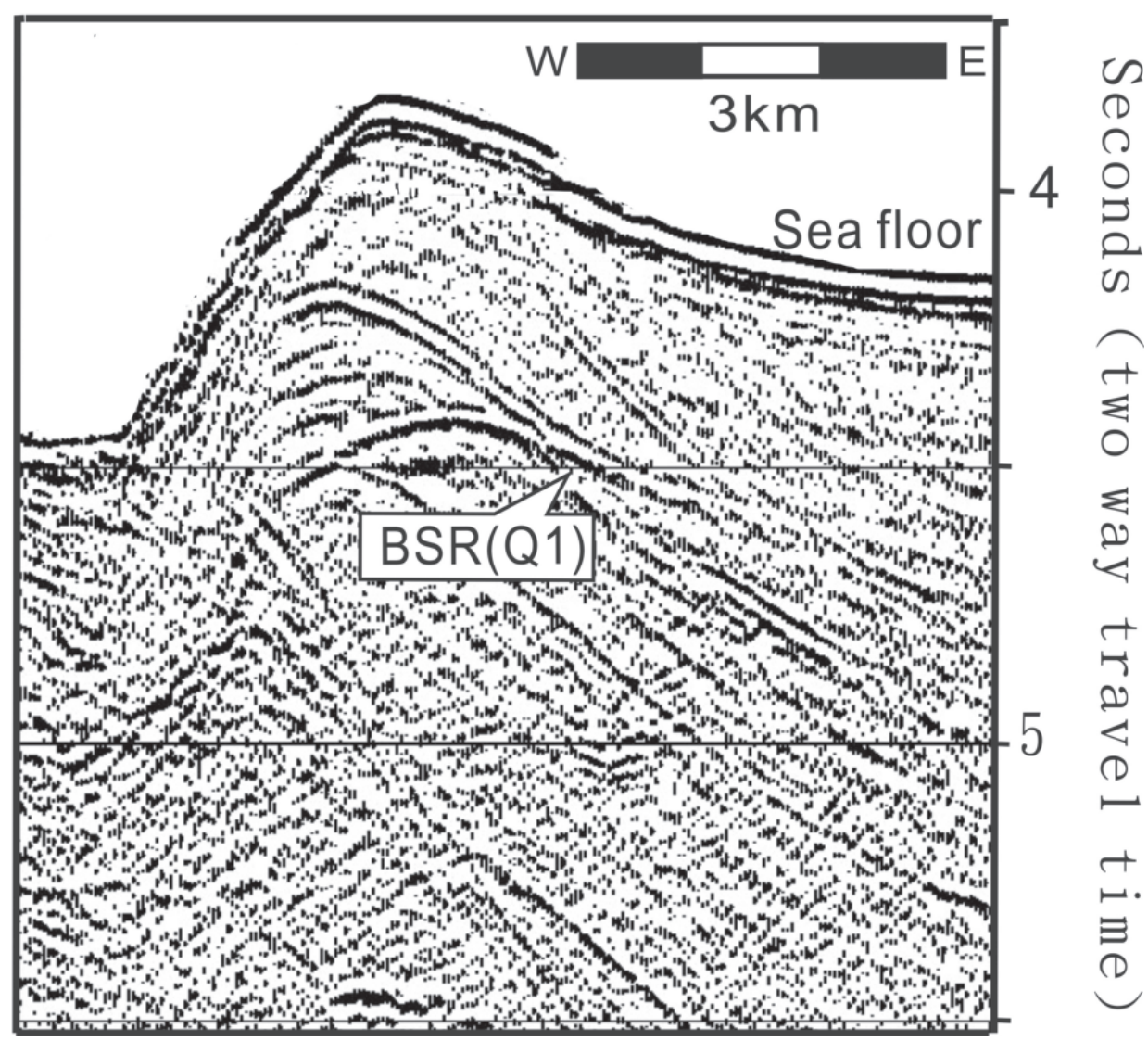

Fig. 3. (a) An example of Q1 class BSR. (b) Examples of Q2 and Q3 BSRs. The locations of these two profiles are marked at the top of the figures and also in Fig. 4. 


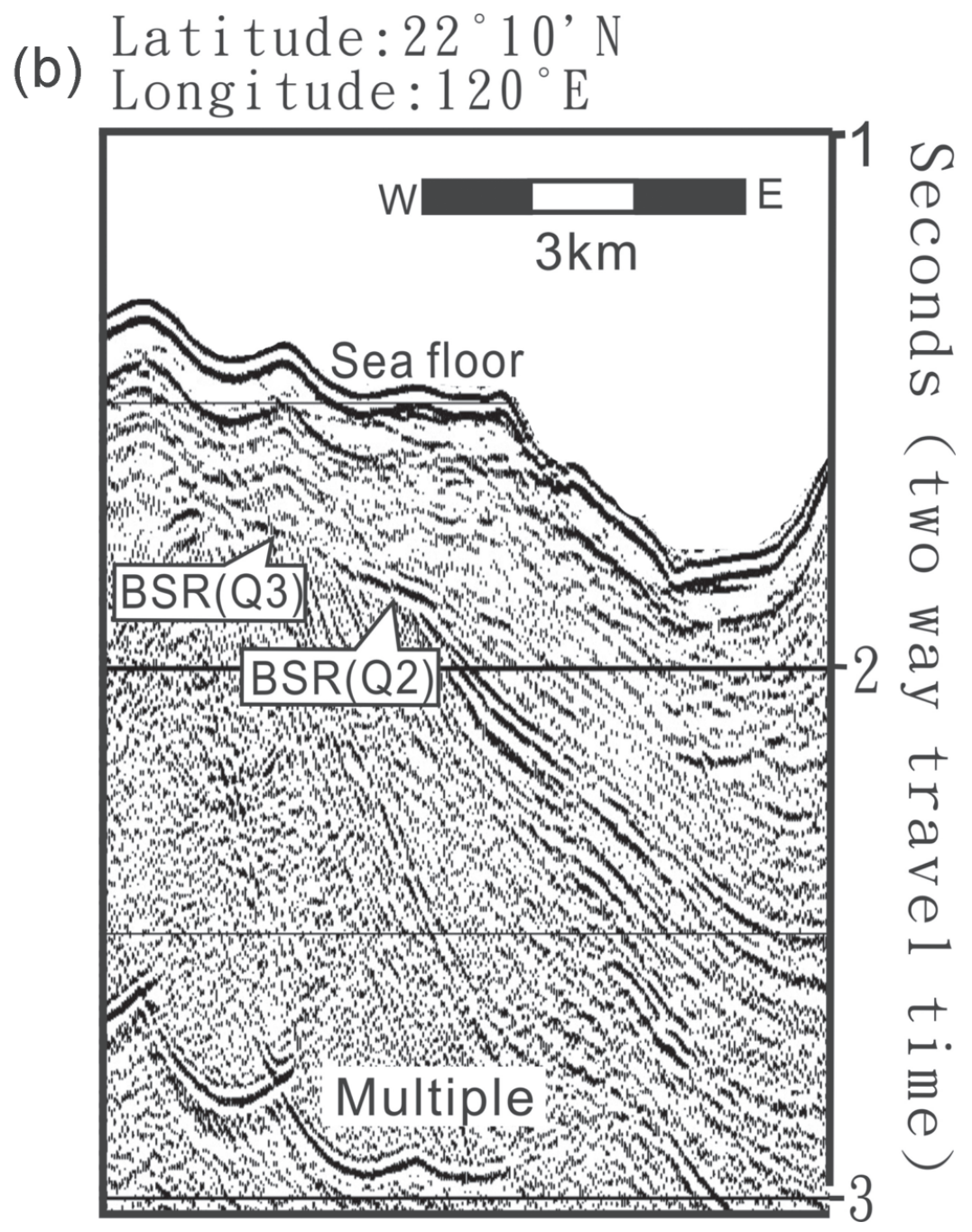

Fig. 3. (Continued)

egory or probable BSR identifications show similar characteristics to the Q1 picks except that the reflections are either segmented into pieces or may not cut bedding. The segment lengths of the Q2 reflectors are usually longer than the gaps between segments. The Q3 category, containing possible BSR picks, exhibits very weak and segmented reflections that are subparallel to the seafloor. BSRs in the Q3 group can be traced from adjacent Q1 or Q2 categories without abrupt changes in the sub-bottom depth. These data were converted into methane 
hydrate distribution maps (Fig. 4). The highest quality (Q1) BSRs are concentrated in the lower domain in the collision zone. The Q2 BSRs are mostly located in the lower slope domain. But some Q2 BSRs are also found in the upper slope domain. The Q3 BSRs can be identified through out the offshore Taiwan accretionary prism and other forearc regions.

The BSR sub-bottom depth ranges from 300 to 600 meters (Fig. 4), which is among the deepest in the world, compared with about $224 \mathrm{~m}$ in northern Cascadia continental slope (Yuan et al. 1996), 100 - $200 \mathrm{~m}$ in offshore Oregon (Shipboard Scientific Party 2003) and many other published works in Blake Ridge and other places. In general, the BSR sub-bottom depth in Taiwan shallows toward the toe of the accretionary prism, despite the increasing water depth, implying a high geothermal gradient along the toe of the accretionary prism. BSR sub-bottom depth also becomes shallower where the Chinese continent enters the subduction zone, even though the water depth decreases. The BSR sub-bottom depth increases from the lower slope domain to the upper slope domain, despite the decreasing water depth.

We then used the distribution of the BSRs and their corresponding BSR sub-bottom depth to estimate the total volume of the hydrate stability field (cf. Table 1). We gridded the offshore region into cells of $0.1^{\circ}$, translating to a size of $10.3 \mathrm{~km}$ by $11.1 \mathrm{~km}$ (Fig. 5). The length of the cell is a bit longer than the spacing of the parallel seismic profiles to avoid a situation where a BSR is present but there are no seismic profiles to sample it. The cells without BSRs were discarded. For the remaining cells, the mapped BSR sub-bottom depths in each cell were averaged before multiplying $114.33 \mathrm{~km}^{2}$ (the surface area for each cell) to derive the volume of the hydrate stability for that particular cell. The numbers of cells containing Q1, Q1 + Q2, and all BSRs are 21, 109, and 215, respectively. The areas covered by Q1, Q1 + Q2, and all BSRs are 2401,12462 , and $24581 \mathrm{~km}^{2}$, respectively. The total volume of the stability field associated with Q1, Q1 + Q2, and all BSRs are 1023, 5517, and $11522 \mathrm{~km}^{3}$, respectively.

\section{DISCUSSION}

Reed et al. (1992) first identified the BSR in this region and interpreted that it is associated with hydrates. Chi et al. (1998) have discussed additional evidence to argue that the BSR around southern Taiwan represents the base of a methane hydrate stability field. The BSR is widespread throughout the accretionary prism, which is composed of offscraped sediments of the Chinese continental margin. It is also widespread in the area of the Taiwan orogen, which may reflect high amounts of organic carbon in rapidly deposited terrigenous sediments. These organic materials may produce either thermogenic or biogenic methane, and other gases, which migrate into anticlines and form gas hydrates.

The gas hydrates are stable below the seafloor when the pressure from the overburden is high. However, once the ridge of the Taiwan accretionary prism gets uplifted or even emerged from the sea due to tectonic movements, the in-situ pressure at the BSR will decrease, and the temperature will increase. As a result, the hydrates will decompose into gases, some of them are likely to escape into the atmosphere. Due to the rapid tectonic deformation in this region and the huge hydrate reservoir estimated from this study, there might have been large amounts of green house gases like methane released into the atmosphere through this mechanism in the last couple of million years (T. F. Yang, personal communication 2006). 


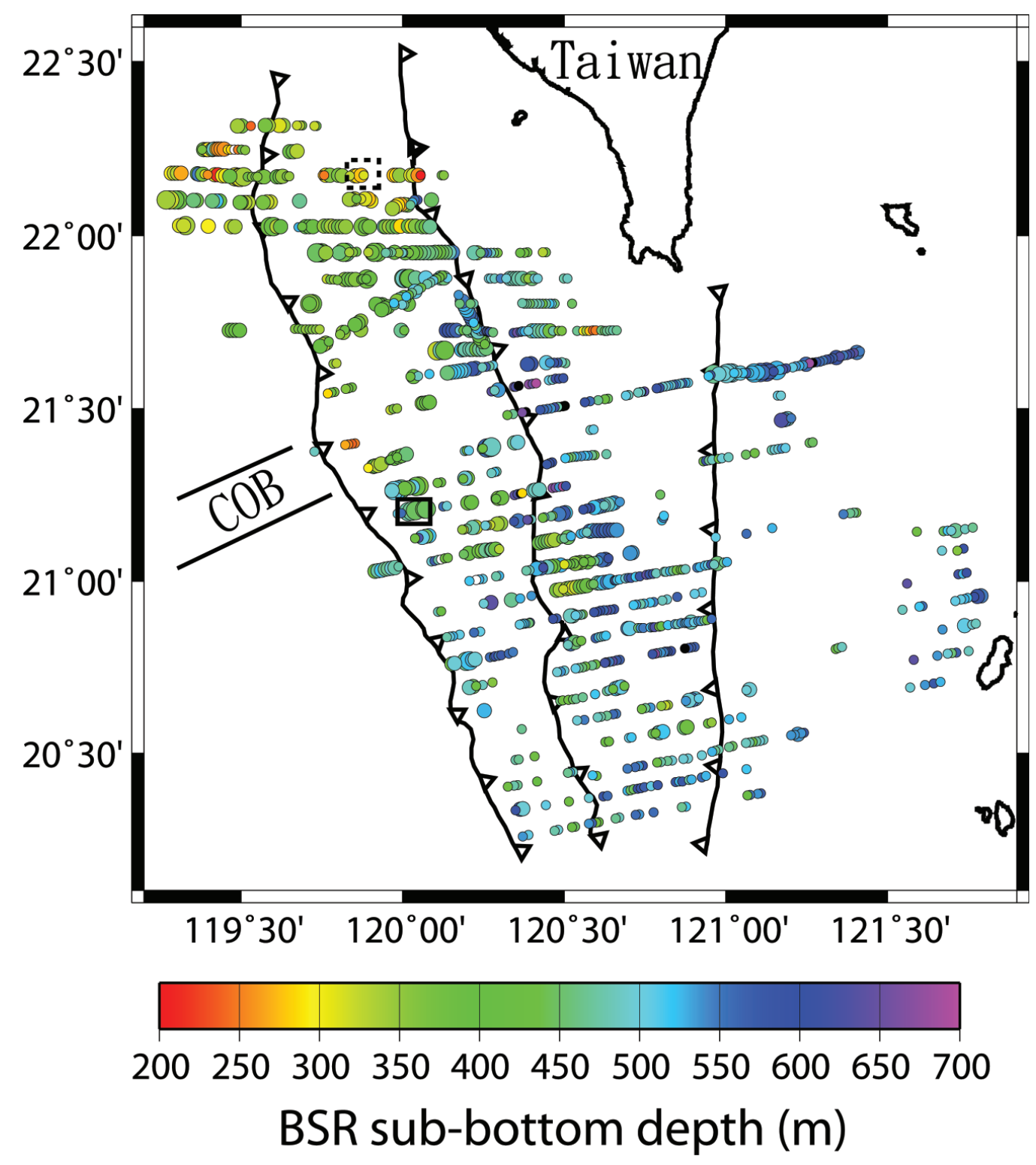

Fig. 4. Distribution of BSR identifications. Large circles indicate Q1 class or highest confidence in BSR identification. Medium circles indicate Q2 class, or probable BSR identification. Small circles indicate Q3 class, or possible BSR identification. The color code shows the BSR sub-bottom depth. The open solid and dashed line rectangles show the locations of the profiles in Figs. 3a and b, respectively. 
Table 1. Volume of the hydrate stability field of offshore southern Taiwan.

\begin{tabular}{|l|l|l|l|l|}
\hline & $\begin{array}{l}\text { Area of } \\
\text { Hydrate } \\
\text { Stability } \\
\text { field } \\
\left(\mathrm{km}^{2}\right)\end{array}$ & $\begin{array}{l}\text { Volume of } \\
\text { Hydrate } \\
\text { Stability field } \\
\left(\mathrm{km}^{3}\right)\end{array}$ & $\begin{array}{l}\text { Volume of } \\
\text { Pore Space in } \\
\text { the Hydrate } \\
\text { Stability Field } \\
\left(\mathrm{km}^{3}\right)\end{array}$ & Remarks \\
\hline $\begin{array}{l}\text { Q1 } \\
\text { (clear BSR) }\end{array}$ & 2401 & 1023 & 475 & $\begin{array}{l}\text { Mostly in the } \\
\text { lower slope } \\
\text { domain in } \\
\text { collision zone }\end{array}$ \\
\hline $\begin{array}{l}\text { Q1 + Q2 } \\
\text { (clear and probable } \\
\text { BSRs) }\end{array}$ & 12462 & 5517 & 2549 & $\begin{array}{l}\text { Mostly in the } \\
\text { lower slope } \\
\text { domain }\end{array}$ \\
\hline $\begin{array}{l}\text { Q1 + Q2 + Q3 } \\
\text { (clear, probable, } \\
\text { and possible } \\
\text { BSRs) }\end{array}$ & 24581 & 11522 & 5284 & $\begin{array}{l}\text { Wide-spread } \\
\text { in the } \\
\text { accretionary } \\
\text { prism }\end{array}$ \\
\hline
\end{tabular}

BSR sub-bottom depths differ from place to place. Uncertainties in measuring the twoway traveltime of the seafloor and the BSR are less than $0.05 \mathrm{~s}$ and therefore significantly less than the range of BSR measurements. There might be additional errors when converting time intervals to depth intervals. Sub-bottom depths of BSRs in two-way traveltime can be influenced by a number of factors like lateral variations in sediment velocity above the BSR and spatial and temporal changes in P-T conditions. The BSR sub-bottom depth in this region ranges from 300 to 600 meters, deeper than many reported elsewhere around the world. This is probably due to the lower regional geothermal gradient, thus the thicker hydrate stability field. As a result, there might be more hydrates per unit area in Taiwan compared with other regions, even though some of the hydrate is located at greater depths and could be difficult to recover.

Next we estimated the total pore space in the stability zone. We use the porosity-depth relation derived at a nearby site FJ1 (cf. Fig. 13 of Lin et al. 2003) that is well-constrained by sonic log data. We converted these interval porosity values at different depths into an average porosity for each BSR. We average the porosities within each cell. The derived average poros- 


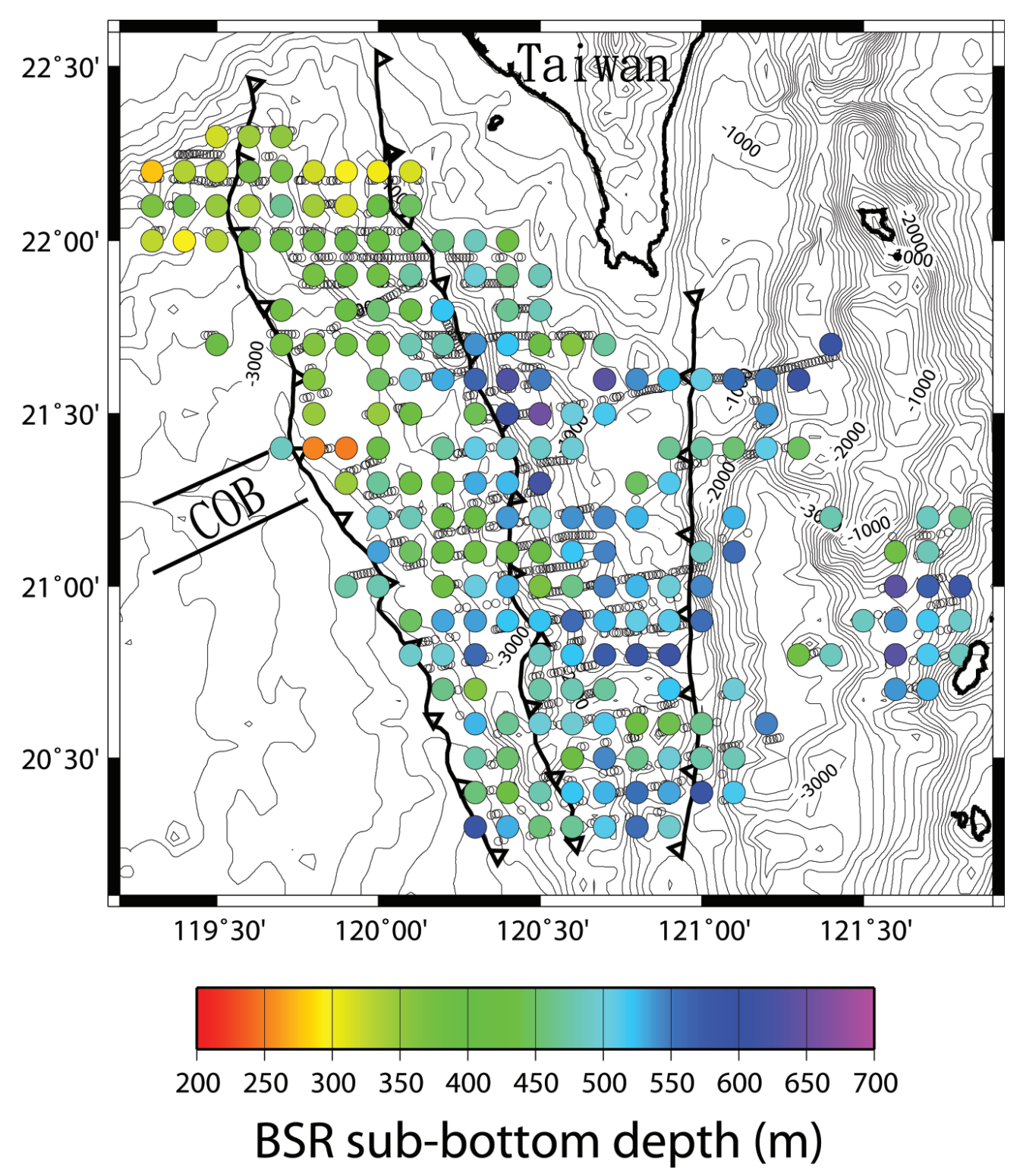

Fig. 5. The circles are the distribution of the BSRs mapped in this study. We gridded this region using a cell size of $0.1^{\circ}$ by $0.1^{\circ}(10.3 \mathrm{~km}$ by $11.1 \mathrm{~km})$ before averaging the BSR sub-bottom depths in the cell. Each color circle represents one cell. The color code shows the average BSR sub-bottom depth of that particular cell. We then calculate the total volume of the hydrate stability field in this region that is associated with mapped BSRs. 
ity ranges between 43 to $50 \%$. We then calculated the total pore space volume in the sediments of the hydrate stability field (Table 1).

We plotted the estimated hydrate storage in the offshore region by multiplying the estimated total pore space volume by a range of hydrate saturation values (Fig. 6). Recently high resolution geophysical and geochemical studies have been conducted at locations near $22.2^{\circ} \mathrm{N}$ and $119.6^{\circ} \mathrm{E}$. The preliminary results give a hydrate saturation value of about $0-10 \%$ of the pore space in the sediments (e.g., Schnürle et al. 2004), translating to up to $47.5 \mathrm{~km}^{3}$ of hydrate if we only count Q1 BSR. It can be as high as $528 \mathrm{~km}^{3}$, if we include all the three types of BSRs. Recent studies elsewhere in the world show that the saturation value of the hydrates in the sediments might vary spatially (Trehu et al. 2003). As a result, even though the stability

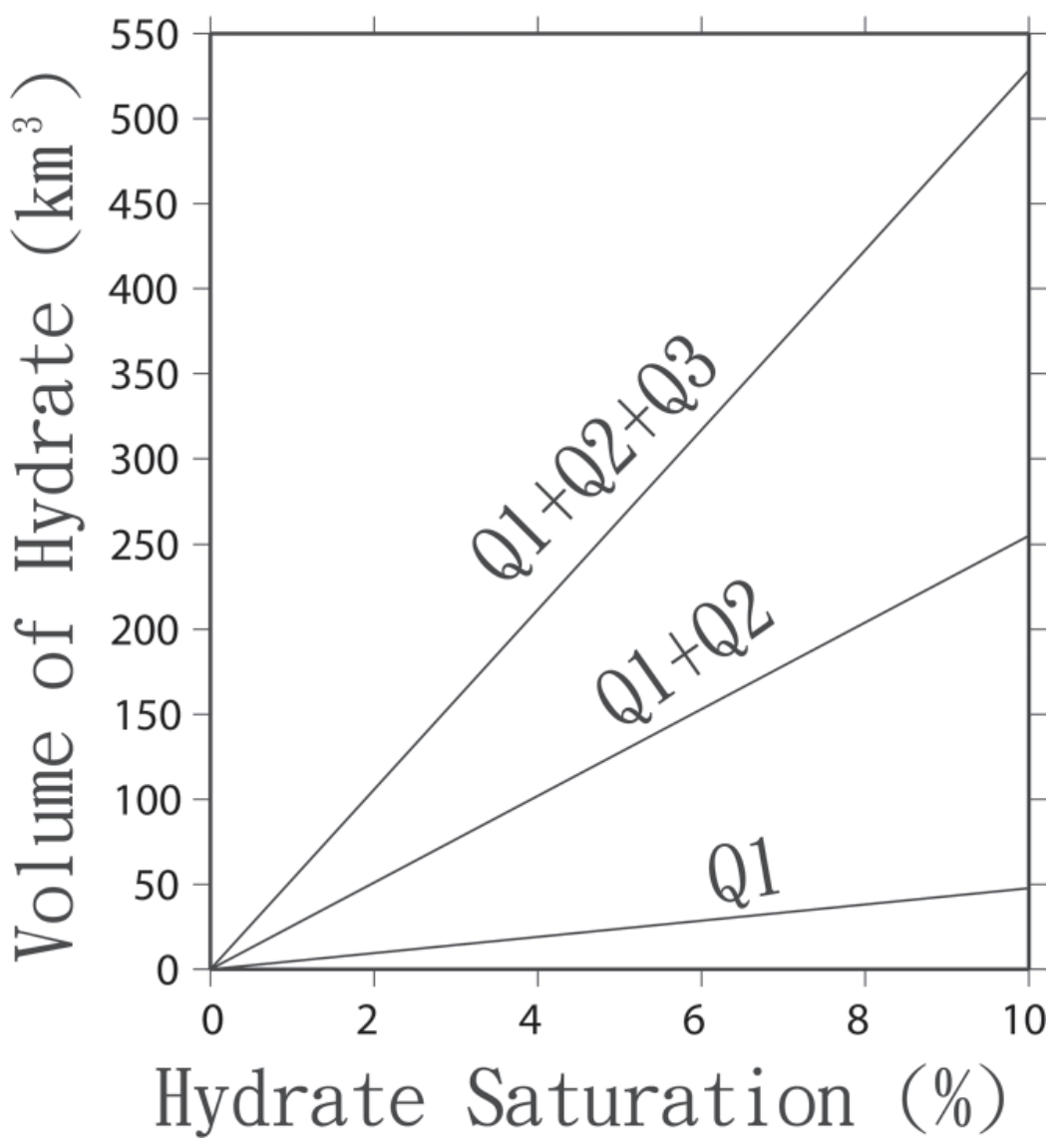

Fig. 6. A hydrate saturation versus volume of hydrate plot. The three lines represent the Q1 BSR, Q1 + Q2 BSR, and all the Q1 + Q2 + Q3 BSRs. 
field estimate from this study should be robust, the estimate for hydrates is preliminary and can be modified once we have a better understanding of the overall regional saturation value. In addition, some BSRs probably were enhanced by the gases underneath the stability field and hydrate concentration probably is highest just above the BSR. In this case, we can also use the area of the hydrate stability field derived from this study to estimate the reservoir more accurately in the future if we have new information about the thickness of the hydrate layer above the BSR and the possible gases below it.

\section{CONCLUSION}

At least $2400 \mathrm{~km}^{2}$ of the Taiwan accretionary prism is covered by a BSR, which is identified as a reflector sub-parallel to the seafloor with reversed polarity. Reversed polarity, increasing sub-bottom depth with increasing water depth, the distribution of the BSR, and methane emitted on land in the nearby region strongly suggests that this feature marks the base of the methane hydrate stability field.

We have classified the BSRs into three categories based on our confidence in identifying the BSR. About $2401 \mathrm{~km}^{2}$ of the sea floor is underlain by the highest (Q1) BSR. If we include all the BSRs $(\mathrm{Q} 1+\mathrm{Q} 2+\mathrm{Q} 3)$ we have identified in this region, the total area underlain by the BSRs can be as high as $24581 \mathrm{~km}^{2}$.

Possibly due to a low geothermal gradient in this region and deeper bathymetry, the BSR sub-bottom depth here ranges from 300 to 600 meters, which is deeper than most of the other BSR sub-bottom depths around the world. This means that the hydrate stability field offshore Taiwan is thick and if hydrate saturation is similar to other gas hydrate regions, the larger hydrate volume may mean it is more economical to recover the hydrates in this region.

Using the BSR distribution and its sub-bottom depth, we estimated the total volume of the hydrate stability field of offshore southern Taiwan associated with 1) Q1 BSR, 2) Q1 + Q2 BSRs, and 3) all the BSRs to be 1023,5517 , and $11522 \mathrm{~km}^{3}$, respectively. In addition, we have also estimated the total pore space in the sediments of the hydrate stability field to be $475 \mathrm{~km}^{3}$ for Q1 BSR, $2549 \mathrm{~km}^{3}$ for Q1 + Q2 BSR, and $5284 \mathrm{~km}^{3}$ for all BSR. These estimates can be used to derive the total hydrate storage in the Taiwan region once we have better understandings of the regional porosity-depth pattern and saturation values of the hydrates in the sediments offshore of southern Taiwan.

Acknowledgments We wish to thank captain and crew of R/V Moana Wave of the University of Hawaii and the captain and crew of R/V Maurice Ewing of Columbia University. We also thank Greg Moore for assistance in seismic data processing. This manuscript benefited greatly from the careful reviews by Dr. Nathan Bangs and Dr. T. K. Wang. Several figures were created by GMT graphic software (Wessel and Smith 1995), and the SIOSEIS processing, developed by P. Henkart, was used to process and plot the seismic reflection data for this study. This work was supported by awards from the National Science Foundation of the USA (OCE-8911690, OCE-9314472, and OCE94-16583) to D. Reed at San Jose State University and National Science Council of Taiwan (NSC 94-2119-M-001-002) to Wu-Cheng Chi. This is Contribution Number 1147 of the Institute of Earth Sciences, Academia Sinica. 


\section{REFERENCES}

Bowin, C., R. S. Lu, C. S. Lee, and H. Schouten, 1978: Plate convergence and accretion in the Taiwan-Luzon region. AAPG Bull., 62, 1645-1672.

Chen, C. H., 1996: Geological features of Taiwan. In: Chen, C. H. (Ed.), Central geological survey, MOEA, Taipei, Taiwan, ROC, $171 \mathrm{pp}$.

Chi, W. C., D. Reed, C. S. Liu, and N. Lundberg, 1998: Distribution of the bottom-simulating reflector in the offshore Taiwan Collision Zone. Terr. Atmos. Ocean. Sci., 9, 779-794.

Hamilton, E. L., 1980: Geoacoustic modeling of the sea floor. J. Acoust. Soc. Am., 68, 13131339.

Ho, C. S., 1986: A synthesis of the geologic evolution of Taiwan. Tectonophysics, 125, 1-16.

House, K. Z., D. P. Schrag, C. F. Harvey, and K. S. Lackner, 2006: Permanent carbon dioxide storage in deep-sea sediments. Proc. Natl. Acad. Sci., 103, 12291-12295, doi: 10.1073/ pnas.0605318103.

Kvenvolden, K. A., 1988: Methane hydrate-a major reservoir of carbon in the shallow geosphere? Chem. Geol., 71, 41-51.

Kvenvolden, K. A., 1993: Gas hydrates-geological perspective and global change. Rev. Geophys., 31, 173-187.

Kvenvolden, K. A., and M. A. McMenamin, 1980: Hydrates of natural gas: a review of their geologic occurrence. US Geol. Surv. Circ., 825, 1-11.

Lin, A. T., A. B. Watts, and S. P. Hesselbo, 2003: Cenozoic stratigraphy and subsidence history of the South China Sea margin in the Taiwan region. Basin Res., 15, 453-478.

Milkov, A. V., 2004: Global estimates of hydrate-bound gas in marine sediments: how much is really out there? Earth-Sci. Rev., 66, 183-197.

Reed, D. L., N. Lundberg, C. S. Liu, and B. Y. Kuo, 1992: Structural relations along the margin of the offshore Taiwan accretionary wedge: implications for accretion and crustal kinematics. Acta Geol. Taiwan., 30, 105-122.

Schnürle, P., C. S. Liu, T. H. Hsiuan, and T. K. Wang, 2004: Characteristics of gas hydrate and free gas offshore southwestern Taiwan from a combined MCS/OBS data analysis. Mar. Geophys. Res., 25, 157-180.

Shipboard Scientific Party, 2003: Leg 204 summary. In: Tréhu, A. M., G. Bohrmann, F. R. Rack, M. E. Torres et al., Proc. ODP, Init. Repts., 204: College Station TX (Ocean Drilling Program), 1-75.

Shipley, T. H., M. H. Houston, R. T. Buffler, F. J. Shaub, K. J. McMillen, J. W. Ladd, and J. L. Worzel, 1979: Seismic evidence for widespread possible gas hydrate horizons on continental slopes and rises. AAPG Bull., 63, 2204-2213.

Suppe, J., 1981: Mechanics of mountain building and metamorphism in Taiwan. Mem. Geol. Soc. China, 4, 67-89.

Trehu, A. M., G. Bohrmann et al., 2003: Proceedings of the Ocean Drilling Program, Initial Reports Volume 204.

Tucholke, B. E., G. M. Byran, and J. I. Ewing, 1977: Gas-hydrate horizons detected in seismic-profiles data from the western Northern Atlantic. AAPG Bull., 61, 698-707. 
Wessel, P., and W. H. F. Smith, 1995: New version of the generic mapping tools released. EOS Trans., AGU, 76, 329.

Yuan, T., R. D. Hyndman, G. D. Spence, and B. Desmons, 1996: Seismic velocity increase and deep-sea gas hydrate concentration above a bottom-simulating reflector on the northern Cascadia continental slope. J. Geophys. Res., 101, 13655-13672.

Chi, W. C., D. L. Reed, and C. C. Tsai, 2006: Gas hydrate stability zone in offshore southern Taiwan. Terr. Atmos. Ocean. Sci., 17, 829-843. 